\title{
The ethics of compulsory removal under Section 47 of the 1948 National Assistance Act
}

Sarah Jane Hobson Manchester University, Manchester

\begin{abstract}
Orders for removal under Section 47 of the 1948

National Assistance Act are little discussed. However, they involve severe infringements of the civil liberties of those affected. It is argued that all previously presented justifications for the use of these orders fail. Repeal of the act is called for. The Law Commission has drafted alternative legislation, but this has not been enacted. Until this occurs local authorities, the Faculty of Public Health Medicine and individual public health physicians should refuse to be involved in its use.

(Fournal of Medical Ethics 1998;24:38-43)
\end{abstract}

Keywords: Public health; compulsory removal; human rights; paternalism

"District Nurse Clara Cook said she was called to the house on December 20th by a neighbour and found Miss Bower sitting on the floor. She refused to let anyone examine her so Dr Hill was sent for, but as she still persisted in her refusal to have attention the doctor applied for a court order for her removal to hospital. Witness added that there was no bed for Miss Bower to go to at her home and from December 20th to December 29th when she was removed to Staincliffe Hospital, Miss Bower remained on the floor. They had no power to remove her."

\section{Introduction}

This paper will examine the use of orders allowing compulsory detention of competent adults under Section 47 of the 1948 National Assistance Act. These orders are used infrequently and so their justification is little discussed and often overlooked. However, they involve a serious interference with the civil liberty and human rights of those affected. I argue strongly that all suggested justifications of these orders fail, and present a way forward to prevent these injustices.

Section 47 , as it is referred to by those who are involved in its implementation, is "for the purpose of securing the necessary care and attention for persons who: a) are suffering from grave chronic disease,,$\stackrel{9}{9} \mathrm{r}$ being aged, infirm or physically incapacitated, 胥e living in unsanitary conditions, and

b) are unable to devote to themselves, and are $\overrightarrow{\mathrm{ng} t}$ receiving from other persons, proper care âpd attention".

It gives discretionary powers which allow, after a seven day delay:

"removal of the person to whom the application relates ... to a suitable hospital or other place in- $\oplus$ r within a convenient distance of, the area of the appropriate authority, and his detention oुand maintenance therein."

The person can then be detained for any peried initially up to three months, which may \&e extended by further three month periods. Follo $\$$ ing the case described above, amending legislation was introduced. This 1951 amendment allows for immediate action, but only in the interests of the individual concerned.

The people affected often live alone in fil thy conditions. Their houses are usually in a pơr state of repair ${ }^{2}$ and lack basic amenities. ${ }^{3}$ ExcEement and rubbish may fill the home and the smell can be overpowering. The people affected arre often medically ill, incontinent and immobile. ${ }^{4}$ Those making orders rarely doubt that so action is required. Our basic instincts are to intervene when faced by such apparent need. The sê tion is not used frequently (there are just over 1.00 removals a year) ${ }^{5}$ but it involves a serious infrin ment of liberty. It is therefore important consider the grounds for acting on these instiness.

\section{In the interests of others}

Some removals are in the interests of others, for the prevention of "injury to the health of, or se ipous nuisance to, other persons". Few will deny validity of the first of these reasons. M, classically one of the strongest defenders gof individual liberty, allows this exception. He writes that "the only purpose for which power can be 
rightfully exercised over any member of a civilised community, against his will, is to prevent harm to others". ${ }^{6}$ Whether we feel that "serious nuisance" can also be classified as harm that is sufficiently great to allow such restrictions is perhaps a more difficult decision. (In law a nuisance is something that causes either physical damage to the neighbour's property or a substantial interference with its use and enjoyment.) In either case the restrictions on an individual's liberty should be kept to a minimum. Such a defence leads us to question whether the act is unjustifiably discriminatory in its application. It is only applicable to those who are old, infirm or disabled. If we wish to allow the state these powers for these reasons, we surely would wish them to apply to all members of society.

Where alternative solutions can be found that are less destructive of individual liberty we should reject this justification of the use of the act. Alternative powers are available to allow cleaning of a house or garden.

\section{In their own interests}

In many cases, and all those using the 1951 amendment, we are ostensibly concerned with the interests of the person detained. We need to consider the extent to which such paternalism is a valid justification. There is some doubt that this infringement of liberty constitutes a benefit. There is a high mortality rate. Studies have found up to $40 \%$ of people dying within three weeks of granting of an order. ${ }^{3}$ We do not know whether this results from removal since poor health often triggers use of the section. On the other hand, there is some evidence that hospitalisation of the elderly in general can increase mortality. ${ }^{7}$ The act does not require recording of its use and with the resulting lack of available data we cannot say removal is always in the interests of the person involved. It seems clear that it sometimes is not.

Referring to use of section 47, Greaves asked the question whether compulsory removal could be justified for adults who were mentally competent. ${ }^{8} \mathrm{He}$ considered the defence of medical treatment would depend on the claim that doctors have a better perception of patients' best interests than they have themselves. He rejected this claim on the grounds that doctor's opinions are just that - opinions. I don't wish to argue with his rejection of medical paternalism. However, the actions are more accurately defined as examples of state rather than medical paternalism. The officers acting under the act are more explicitly agents of the state than is the case within a standard clinical encounter.
Legal confusion over the role expected of doctors carrying out these procedures is important. The relevance of the medical function is unclear. The original intention of the act was that the proper officer should be a registered medical practitioner. However, many hold that this qualification is not necessary. ${ }^{9}$ Uncertainty also arises over the intended effect of removal. The act gives removal to hospital as one option. We tend to associate residence in hospital with treatment. Often people detained under these orders will accept treatment after admission. Compulsory treatment is not, however, provided for in the act itself. Those involved in implementing the orders are also unclear as to who has the power to discharge the patient. One writer discusses a situation where a man was illegally discharged by doctors before the order had expired, against the advice of the proper officer who had originally certified the need for the order. ${ }^{10}$

Medicine is fogging the issue. Illness is not the basis for the action and the proper officer need not be medically competent. We should forget the medical model.

Greave's criticism of the action loses force where the proper officer is not merely voicing an individual opinion but that of the public. The relevance of public opinion is demonstrated when we try to identify who might have a legal duty as opposed to a right to use the legislation. There is no legal liability resulting from inaction, no case for personal injury or negligence against the proper officer. However, he or she is answerable to the coroner or the local authority if problems arise. The local authority in turn is answerable to the electorate. Media interest is great in these cases.

\section{Public opinion}

The pressure of public opinion perhaps reflects a more general belief that we should act even where this duty is not enshrined in law. The popular view is that someone should intervene in these cases. However, we should not infer any act is an ethical duty solely on the basis of its wide acceptance.

Mill's firm rejection of paternalism was developed specifically because he was aware of the potential "tyranny of the majority". Having described the development of popular government he writes:

"It was now perceived that such phrases as 'self government', and 'the power of the people over themselves', do not express the true state of the case. The 'people' who exercise the power are not always the same people with those over whom it is exercised; and the 'self government' spoken of is 
not the government of each by himself, but of each by all the rest... . The limitation, therefore, of the power of government over individuals loses none of its importance when the holders of power are regularly accountable to the community, that is, to the strongest party therein."

Mill recognises tyranny is not restricted to political power. He saw the power of governmentality long before Foucault coined the word. ${ }^{11}$

"Like other tyrannies, the tyranny of the majority was at first, and is still vulgarly, held in dread, chiefly as operating through the acts of the public authorities. But reflecting persons perceived that when society is itself the tyrant - society collectively over the separate individuals who compose it - its means of tyrannising are not restricted to the acts which it may do by the hands of its political functionaries. Society ... practises a social tyranny more formidable than many kinds of political oppression."

I do not wish to challenge Mill's claim that individuals are the most appropriate judges of their own interests. I will examine next the justifications of paternalistic interventions which stand even when this claim is accepted. These depend on some notion of consent being given.

Paternalism is generally attacked on the grounds that it infringes individual autonomy that it restricts freedom of choice. This has two adverse effects. Firstly, it is claimed that people are the best judges of what is in their interests. Paternalistic restrictions are liable to be themselves based on inaccurate information. Secondly, and probably more importantly, the process of choosing - the actual liberty to make decisions regarding what happens to us - is an important good in itself, regardless of what choice is made. Where informed consent is given, a true free choice has been made. Autonomy is not affected and the paternalist may be able to justify his or her intervention.

\section{Consent}

In the case of section 47 consent is obviously not contemporaneous. However, Dworkin suggests that we can sometimes apply the notion of prior consent. ${ }^{12} \mathrm{He}$ starts with the example of Odysseus who ordered his companions to tie him to his ship's mast and ignore his later requests to be untied. In this way Odysseus was able to hear the beautiful song of the sirens without succumbing to their fatal attraction. His prior consent to having his subsequent wishes overruled worked for his own good and his greater autonomy. Dworkin extends this example to situations where the man- date for the action is very specific. He suggests the concept of a "social insurance policy" whereby can "consent to a system of government, run by elected representatives, with an understanding that they may act to safeguard our interests in ce? tain limited ways". ${ }^{12}$ Such insurance allows peop to protect themselves against future dangerogs conduct. He limits the possible use of thes consent, in order to protect against its abuse, to situations where the overridden decisions are "ferr reaching, potentially dangerous, and irreversible". ${ }^{16}$ The goods endangered must be the prerequisites to other goods and the choices mut be seen to be irrational. Such irrationality will recognised where the decisions don't express tT actual preference of the individuals (perhaps because emotional reaction to risks overwhelms the intellect) or where the individual appears $q \theta$ have "evaluative delusions" and is unable to make accurate assessments of risk.

\section{Counterarguments}

At first sight the individuals affected by section $\overrightarrow{2}$ would seem to form a group to whom this seipl insurance policy might apply. Their decision remain at home are potentially dangerous, in one might suppose often fatally so. Health and life are prerequisites to many other goods. It कs difficult for those intervening not to believe that some evaluative delusions must be present, $\overrightarrow{\text { क् }}$ such refusal of help appears irrational. However, three counterarguments can be given.

Firstly, there is little evidence of prior consent having been given. Although one researcher fouñ elderly patients supported the act, ${ }^{13}$ his study population was probably significantly differeăt from the population to whom the act is applieg. There is some evidence that individuals who fall foul of the act have been lifelong eccentrics.

Secondly, the use of prior consent can only be justified where contemporaneous consent is net available. To assume this we must be able to argae that the person refusing removal is incompetentin some way. The section does not require compes tence to be examined. Without further expliêt examination, the judgment of incompetence must be based on the assumption that no rational person would choose to live in such a state. However, we know that this assumption is incorrect. Disgusting behaviour is not always irration behaviour. As Dworkin states in a more receğt discussion:

“... No one may be prevented from influencing the shared moral environment, through his own private choices, tastes, opinions, and example, just 
because these tastes or opinions disgust those who have the power to shut him up or lock him up."14

We are in danger of exhibiting the very tyranny of the majority we set out to avoid.

In addition, when the outcome of removal includes such a high risk of death the irrationality of the decisions is less clear. The individuals may, indeed, be more aware of their best interests than the professionals. There may be no "evaluative delusions". Perhaps it is the professionals who suffer from delusions, as they act despite lack of hard evidence of the benefits of removal. Their judgments are based on gut feelings that the situations cannot but be improved upon. It is their emotions rather than their reasoning that leads to this conclusion. Whatever the strength of Dworkin's position on prior consent, it seems doubtful that it should be applied here.

If we reject the notion of prior consent, can we consider retrospective consent? Studies cite examples of situations where retrospective consent has apparently been given. Wolfson and Muir Gray describe people who are later happy to have been removed. ${ }^{4}{ }^{15}$ However, this cannot affect the legitimacy of the intervention. It seems ridiculous to say that the final decision on the morality of apparently identical actions can be decided in such a haphazard fashion. Intuitively, there is something wrong with this argument. It assumes a continuity of the wishes of the person affected that is shown to be false by the very alteration in that person's view over time.

It does not seem that we can claim that the people concerned have consented to their treatment in any way. The actions cannot be justified. The claim that consent is irrelevant since the people are incompetent ignores the fact that the section at no time requires the competence of the person affected to be considered in any way.

\section{Trust and respect}

Greaves suggests a different perspective where:

"the resolution of this ethical dilemma requires a different moral conception, involving the recognition that there is an inevitable conflict of view between the patient and the community doctor, and that both sides be respected by being taken seriously."

Greaves feels that the underlying trust in the doctor - patient relationship is the important factor in justifying these actions. Rejection of the medical model undermines this point. In addition it seems ludicrous to talk of trust occurring between the subject of the order and its executor.

Muir Gray argues similarly.
"When I use section $47 \mathrm{I}$ am in effect saying ' $\mathrm{I}$ respect your opinion, I believe that you are sane and that it is a valid opinion but I also believe that it is wrong'". ${ }^{16}$

It is difficult to see what is meant by "respect" in this situation. One would generally expect showing respect to other people's opinions to require that we allow them to act on these opinions. This is clearly not what Muir Gray means. Just as the trust identified by Greaves does not involve the patient, so the mutual respect experienced by Muir Gray seems very lopsided.

\section{In the public interest}

Less explicit motives for use of this act have been suggested. Firstly it may result from rationing. In 1987, a community physician applied for an order on the grounds that the patient required more nursing care than the district service could supply. The magistrates refused the order for other reasons but the argument regarding the cost of community care was not explicitly rejected. ${ }^{17}$ Muir Gray claims this is a real ethical issue, drawing a parallel with renal transplantation rationing. In both, he suggests, the professional's definition of need is influenced by shortage of resources. ${ }^{15}$

Andrew Grubb suggests there is a public interest in showing care to those who suffer. He writes:

"A doctor cannot be required to refrain from treating a patient so that in effect, the patient is abandoned. A patient probably, therefore, could not validly refuse basic care in the form of what is often termed 'nursing care'. Public policy would prohibit a patient refusing such treatment."18

The Law Commission suggested that this argument could extend to capable patients, claiming that this would not be a significant infringement of the patient's rights of self determination. ${ }^{19} \mathrm{How}$ ever, this argument appears to be shaky when applied to section 47 . Here we are discussing serious infringements of individual liberty. Even if we were to accept the validity of a utilitarian weighting, the costs to the individual must surely outweigh the benefits to society.

Another possible motivation is the potential of section 47 to control social deviance. In this respect Muir Gray refers to the well known debate following the publication of the Wolfenden report regarding the justification of such use of the law to enforce society's morals. Again we must fear that the act is an example of the potential tyranny of the state so clearly laid out by Mill.

If we accept these more utilitarian arguments for interventions in the public interest, the act still remains deficient. If it is society's best interests 
which form the underlying basis for the decision this should be explicitly stated, not disguised as action in the individual's best interests.

\section{Conclusion}

Society has changed considerably since this act was written. Paternalism is less acceptable. We generally reject the role of the state in enforcing morals. The discussion above demonstrates that attempts to justify its actions in the interests of those removed are all flawed. If we wish to base the justification on the utilitarian argument for the public interest or on the incapacity of those removed to consent, this should at least be explicitly stated. Despite the lack of valid justifications this section remains in use.

\section{What should be done?}

This raises the question of how professionals should act when faced by bad laws. The first option is to attempt to change the law. Legal moves have been made to bring about reform. Questions have been asked in the House of Commons on several occasions regarding: the frequency of use of the section; the steps taken to monitor its use, and provision of guidance on its application for medical and social work practitioners. ${ }^{20}$ Representations have been made to the secretary of state advocating replacement of the section. The need for repeal and reform of this section has been recognised by the Law Commission, following extensive public consultation. The commission has drafted alternative legislation based on assessment of the mental capacity of affected individuals rather than their health or age. ${ }^{21}$ However, these laws remain unenacted.

It is worth considering what led to the 1951 amendment. The case of Miss Bower interested the media, raising the profile of the issue. Attempts to publicise the problems, for example by writing as I do here and others have before $\mathrm{me}^{22-25}$ must surely be legitimate. Legal challenges, perhaps looking to challenge the laws in the European courts on the basis of their apparent infringement of human rights ${ }^{26}$ would also highlight the cases. Can we, indeed should we, go further?

At an organisational level, local authorities could voluntarily stop using this section. In order to protect individuals from blame or unwarranted personal media pressure, the role of proper officer for this section could be left unfilled. If the authorities fail to act in this way, individuals could act by refusing to accept the role. The Faculty of Public Health Medicine could facilitate this by supporting such actions by its members. Positi得 action such as that suggested would hasten if introduction.

The morality of such approaches requires further consideration. There are sometimes un derlying problems involving individuals in real need of care which cannot at present be answeref in any other way than use of section 47 . Is it rig席 to deny what may be the best available, although admittedly imperfect, option to one person in thre hope of improving the law for others? Is it reaso $\overrightarrow{0}$ able to expect individual proper officers to risk unpleasant media criticism in such a cause? Dos the doctors involved have an absolute duty publicise these cases, or do the personal ris involved make this a superogatory duty?

These are not easy cases, they challenge âd involved. Unfortunately the present legislatiof hinders the finding of the best solutions. It 18 unnecessarily restrictive of the liberty of those to whom it applies. It gives inadequate safeguards yo those in danger of removal and those undertaking it. It is an example of state tyranny that cannot defended. As such, it is in the best interests of ne one. Continuing its use conceals the need $\mathrm{f}_{\mathrm{O}}$ reform and so delays the introduction of altethin tive legislation.

Sarah fane Hobson, BSc, MB ChB, MA, MRCGP, a Specialist Registrar in Public Health Medicine, the School of Epidemiology and Public Health, the University of Manchester and a PhD Student at the same university's Centre for Social Ethics and Polic

\section{References}

1 Won't go to hospital. The Batley Reporter 1951 Jan 20: 2.

2 Towler JN. "47 varieties". A survey of the use of section 47 of the National Assistance Act 1948 in Bradford. Public Heatoh 1988;102:485-92.

3 Victor CR. Section 47 removals: do they benefit the patien Geriatric Medicine 1989;19,9:24-6.

4 Wolfson P, Cohen M, Lindesay J, Murphy E. Section 47 and tits use with mentally disordered people. Fournal of Public Heath Medicine 1990;12:9-14.

5 Nair P, Mayberry JF. The compulsory removal of elderly peofé in England and Wales under section 47 of the National Assistance Act and its 1951 amendment: a survey of its implementation in England and Wales in 1988 and 1989. Age and Ageing 1995;24:180-4.

6 Mill JS. Utilitarianism. On liberty. Essay on Bentham. Glasgdo Fontana Press, 1962.

7 Rai GS, Beilawska C, Murphy PJ, Wright G. Hazards for eldecty people admitted for respite ("holiday admissions") and social care ("social admissions"). British Medical fournal 1986;2\%: 240.

8 Greaves DA. Can compulsory removal ever be justified for adults who are mentally competent? fournal of Medical Ethios 1991;17:189-94.

9 Public Health Legal Information Unit. The National Assista Acts 1948 and 1951: section 47 removals. Buxton: James Buttọ,
1996.

10 Counsell E. Compulsory removal and medical discretion. Not Law fournal 1990 May 25:750-1.

11 Foucault M. Governmentality. In: Burchell G, Gordon C, Miller P, eds. The Foucault effect. London: Harvester Wheatsheaf, 1984.

12 Dworkin G. Paternalism. The Monist 1972; 56,1:64-84. 
13 Mayberry JF. The views of professionals and patients on compulsory removal from home to an institution (section 47, National Assistance Act). Health and Social Care in the Community 1996;4:208-14.

14 Dworkin G. Freedom's law. Oxford: Oxford University Press, 1996:238.

15 Muir Gray JA. "Section 47". Fournal of Medical Ethics $1981 ; 7: 146-9$.

16 Muir Gray JA. Section 47 - assault on or protection of the freedom of the individual? A short response to Greaves. Fournal of Medical Ethics 1991;17:195, 204.

17 Brahams D. Involuntary hospital admissions under section 47 of the National Assistance Act. The Lancet 1987;2: 406.

18 Grubb A. Commentary. Medical Law Review 1993;84:84-7.
19 Law Commission. Consultation paper 129. London: HMSO, 1993: 390

20 For example see Mr Bowden's question of $17 \mathrm{July,} \mathrm{1990.} \mathrm{Parlia-}$ mentary debates. Commons. Hansard vol 176, col 512w.

21 Law Commission. Mental incapacity. Law com No 231 CMD. London: HMSO, 1995.

22 Fear JD, Hatton P, Renvoise EB [letter]. British Medical fournal $1988 ; 296 ; 860$

23 Davis AR [letter]. Fournal of Public Health Medicine 1990;12: 213-6.

24 Murphy E [letter]. Age and Ageing 1995;24:543.

25 Hobson S [letter]. The Lancet 1997;349:1482.

26 Hoggett B. Mental health law. London: Sweet and Maxwell, 1996. 